\title{
Evaluation of induction of somatic embryogenesis from cotyledonary leaves of Banana Passion fruit (Passiflora mollissima) L.H Bailey
}

Evaluación de la inducción de embriogénesis somática a partir de hojas cotiledonares de curuba de castilla (Passiflora mollissima) L.H Bailey

\author{
Oscar José Parra-Peñalosa ${ }^{1}$, Giovanni Orlando Cancino-Escalante ${ }^{2 *}$ \\ Biologist, oscarjo_parra@outlook.com, ORCID: 0000-0002-8548-6737, Universidad de Pamplona, Pamplona, Colombia. \\ PhD in Science, gcancino@unipamplona.edu.co, ORCID: 0000-0002-3812-1129, Universidad de Pamplona, Pamplona, Colombia.
}

How to cite: O. Parra-Peñalosa and G. Cancino-Escalante, "Evaluation of induction of somatic embryogenesis from cotyledonary leaves of Banana Passion fruit (Passiflora mollissima) L.H Bailey. Respuestas, vol. 24, no. 3, pp. 31-38, 2019.

Received on February 12, 2018 - Approved on June 15, 2018

\section{ABSTRACT}

\section{Keywords:}

Banana passion fruit, Curuba, Embryos, In vitro, Organogenesis, Passifloras.

Passiflora mollissima L.H Bailey is an endemic species from the Andes mountain of Colombia in South America with important edible fruits and medicinal and economical properties. The development of improved micropropagation techniques is necessary to provide rapid and efficient clonal propagation of elite genotypes with high resistance and uniform production, as well as a system that can be used for genetic transformation. For this reason, the investigation focused on the evaluation of induction of somatic embryogenesis in $P$. mollissima from cotyledonary leaves, the effect of growth regulator concentrations and the orientation of explants on embryo production. Histological analyses of somatic embryogenesis were performed every 10 days after induction over 38 days of exposure to the medium. Results showed somatic embryo formation on Murashige and Skoog, (1962) culture medium supplemented with $4.5 \mu \mathrm{M}$ 2,4-diclorophenoxyacetic acid plus $4.5 \mu \mathrm{M}$ 6-benzyladenine. The results obtained are applicable to knowledge of non-zygotic embryogenesis in passionflower of the Andean region, for the purpose of improvement and commercial use. It is noteworthy that this is the first study in the induction and obtaining of embryos in P. mollissima.

\section{RESUMEN}

\section{Palabras clave:}

Fruta de la pasión, Curuba de castilla, Embriones, In vitro, Organogénesis, Pasifloras.
Passiflora mollissima L.H Bailey es una especie endémica de los Andes de Colombia sus frutos son comestibles y presentan propiedades medicinales. El desarrollo de técnicas de micropropagación permiten proporcionar una propagación clonal rápida y eficiente de genotipos de élite con alta resistencia y producción uniforme, así como un sistema que pueda usarse para la transformación genética. Por esta razón, la investigación se centró en la evaluación de la inducción de embriogénesis somática en $P$. mollissima a partir de hojas cotiledonarias, el efecto de las concentraciones del regulador de crecimiento y la orientación de los explantes en la producción de embriones. Los análisis histológicos de la embriogénesis somática se realizaron cada 10 días después de la inducción durante más de 38 días de exposición al medio. Los resultados mostraron la formación de embriones somáticos en el medio de cultivo Murashige y Skoog, (1962) suplementado con ácido 2,4-diclorofenoxiacético 4,5 $\mu \mathrm{M}$ más 6-benciladenina 4,5 $\mu \mathrm{M}$. Los alcances de esta investigacion son aplicables al conocimiento de la embriogénesis no cigótica en las pasifloras de la región andina, con fines de mejora y uso comercial. Es de destacar que este es el primer estudio en la inducción y obtención de embriones en P. mollissima. 


\section{Introduction}

Passiflora is the largest and most important genus of the Passifloraceae family, comprising about 575 species [1]. In North America and Europe, the main species, P. incarnata, is popularly known as passion fruit or passion flower, while in South America, the most cultivated species are $P$. edulis var. edulis, $P$. edulis var. flavicarpa, P. mollissima var. mollissima [2].

P. mollissima is commonly known as "curuba de castilla" or "banana passion fruit", and it grows as a vigorous climber in climates with average temperatures between 13 and $16^{\circ} \mathrm{C}$. Some varieties adapt to altitudes from 1,700 to 3,000 meters above sea level (m.a.s.l) however, altitudes below 1,000 meters increase the incidence of pests and above 2,500 meters of diseases [3]. In Colombia, it is highly valued in the commercial market for not only its edible fruit but also for its nutritional and medicinal properties. Production is destined to both local and international markets and the largest importer is Europe [4].

With regards to the percentage of seed germination, growth rate and viability of seedlings [5] established that for some Passiflora species seedling developed after 65-90 days of culture and for P. mollissima, in particular, presented lower germination rates when compared to other species [6] hence, in vitro propagation (micropropagation, embryogenesis) is an alternative to traditional methods [7].

The first in vitro studies developed in Passifloras were reported in Passiflora caerulea L. [8] and P. edulis f. flavicarpa and Passiflora molissima (Kunth) LH Bailey [9] which focused on the induction of organogenesis. Other procedures such as non-zygotic organogenesis and embryogenesis, that offer rapid large-scale propagation, have been developed (10). As for studies of somatic embryogenesis research has been conducted in P. edulis [11], [12]; P. cincinnata [13], P. foetida [14] and $P$. ligularis [15], however, at present the induction of somatic embryogenesis from zygotic embryos or leaf explants of $P$. mollissima has not yet been reported.

In this respect somatic embryogenesis offers many advantages over conventional micropropagation such as low rate of genetic variation, culture of a large number of somatic embryos (up to 1.35 million somatic embryos capable of being regenerated per liter of medium) and root/shoot formation is simultaneous during regeneration, thus eliminating the need for a root induction phase [16]. Therefore, the aim of this study is to evaluate the induction of somatic embryogenesis from cotyledonary leaves and the effect of the orientation of explants adaxially or abaxially side-up on culture medium in order to propose reproducible methodology for embryo production with application in mass propagation and genetic transformation of P.tripartita.

\section{Materials and methods}

\section{Plant material}

Ripe fruits of $P$. mollissima were purchased in the main market of the municipality of Pamplona, North of Santander, Colombia. Fruits selected presented good phytosanitary characteristics, that is, an optimal state of maturity, without the presence of pathogens and with a vigorous shape and texture. Approximately 10 $\mathrm{kg}$ of fruit were processed by blanching and pulping the fruit in order to separate the seeds and arils from the peels. After washing and drying $\left(60{ }^{\circ} \mathrm{C}\right.$ for $\left.12 \mathrm{~h}\right)$, the seeds were ground by a knife mill (Grindomix GM200-Retsch GmbH, Haan,Germany) using dry ice, vacuum-packed and stored at $-20{ }^{\circ} \mathrm{C}$.

\section{Seed germination}

To establish seedling/plants of $P$. mollissima seeds were soaked in sterile water for $2 \mathrm{~d}$ then surface sterilized $(5 \mathrm{~min})$ by immersion in $70 \%(\mathrm{v} / \mathrm{v})$ ethanol, followed by a second immersion in $30 \%$ (v/v) bleach solution. Seeds were rinsed 7-10 times with sterile water and then placed in germination trays, which contained organic substrate that gave them support and nutrition. Germination trays were taken to the incubation room at a temperature of 16 to $22{ }^{\circ} \mathrm{C}$ and a photoperiod of 16 light hours and 8 dark hours. The germination time until reaching the seedling state lasted approximately 28-40 days. The seedlings with 3-5 leaves and 2-4 roots were used as donor plants.

\section{Explant preparation and surface sterilization of explants}

After 28-40 days when the germinated seedlings opened their cotyledonary leaves, they were cut 
and immediately placed in a solution of ascorbic acid $(0.1 \% \mathrm{p} / \mathrm{v})$ to prevent oxidation. The methodology used was the one proposed by da [11], and modifications were made in terms of exposure times and types of solutions used. Leaf explants were washed five times with sterile water, then they were passed through $2 \%(\mathrm{v} / \mathrm{v})$ sodium hypochlorite for 30 minutes under constant agitation; washed again with sterile water and finally passed through a $3.5 \%(\mathrm{v} / \mathrm{v})$ isodine ${ }^{\circledR}$ solution for 30 minutes also under constant agitation. Then explants were rinsed 7-10 times with sterile water. This whole process was carried out in a laminar flow cabinet to guarantee total asepsis.

\section{Induction of somatic embryogenesis.}

To determine the effect of orientation of explants on callus induction and shoot proliferation cotyledonary leaf explants were cultured with their abaxial/adaxial surface in firm contact with the medium. In order to evaluate the effect of the growth regulators for the induction of somatic embryogenesis, about 1-cm-long leaves excised from donor plantlets were used as explants. The culture medium used was [17] (MS) based-medium, added with vitamins such as thiamine $(0.1 \% \mathrm{v} / \mathrm{v})$, nicotinic acid $(0.01 \%$ $\mathrm{v} / \mathrm{v})$, pyridoxine $(0.01 \% \mathrm{v} / \mathrm{v})$, and myo-inositol $(0.1 \% \mathrm{v} / \mathrm{v})$, also $3 \%$ sucrose and the plant-agar gelling agent $(0.7 \% \mathrm{v} / \mathrm{v})$. MS based-medium was supplemented with different concentrations of the growth regulators 2, 4-dichlorophenoxyacetic acid (2.4 D) $(4.5 \mu \mathrm{M}, 18.1 \mu \mathrm{M}$ and $27.1 \mu \mathrm{M})$ and a constant concentration of Benzylaminopurine (BA) $(4,5 \mu \mathrm{M})$ (Table 1). The $\mathrm{pH}$ of the media was adjusted to 5.7 with $1 \mathrm{~N} \mathrm{KOH}$ or $\mathrm{HCl}$ prior to autoclaving for $15 \mathrm{~min}$ at $121{ }^{\circ} \mathrm{C}$. Explants were incubated in $175 \mathrm{ml}$ capacity glass jars under a 16-h photoperiod at 28-36 $\mu \mathrm{mol} \mathrm{m} \mathrm{m}^{-2} \mathrm{~s}^{-1}$ (daylight fluorescent tubes FL- 30D/29, $40 \mathrm{~W}$, Centrales Electricas Co., Pamplona) and $22 \pm 2 \circ \mathrm{C}$.

\section{Experimental design}

For the evaluation of the experiments 4 treatment levels were designed (Table I). The percentage of embryogenic callus formed by explant, the types of embryos formed and the total number of embryos were quantified using an Image $₫$ digital processing software version 1.8 [18] and observed with a stereoscope.

Table I. Growth regulator concentrations evaluated in induction of somatic embryogenesis

\begin{tabular}{|c|c|c|}
\hline Level & $\mathbf{B A}(\boldsymbol{\mu M})$ & $\mathbf{2 , 4 D}(\boldsymbol{\mu M})$ \\
\hline 0 & 0 & 0 \\
\hline 1 & 4.5 & 4.5 \\
\hline 2 & 4.5 & 18.1 \\
\hline 3 & 4.5 & 27.1 \\
\hline
\end{tabular}

\section{Statistical analysis}

All experiments were carried in completely randomized design (CRD) with ten replications were performed for each treatment level and represented by two explants in each replicate (jar as a replicate). The tests applied corresponded to non-parametric analysis due to the distribution presented by the data.

In order to determine the effect of planting orientation on the embryogenic callus percentage and the total number of embryos a comparison test was applied to two independent Mann-Whitney samples ( $\mathrm{p}<$ 0.05). For the determination of the effect of the plant growth regulator concentrations a Kruskal-Wallis test $(\mathrm{p}<0.05)$ was used.

\section{Histological tissue studies}

The embryos formed in the different stages were used as samples and a cytology study was carried out for visual analysis of somatic pro-embryonic cells. Pro-embryonic masses were stained with Evans blue $(0.5 \%)$ for $3 \mathrm{~min}$ and aceto-lactic orcein $(2 \%)$ for $3 \mathrm{~min}$. Explants bearing somatic embryos were fixed in FAA (formalin, acetic acid, ethyl alcohol 50\%) for $24 \mathrm{~h}$, washed in $70 \%$ alcohol, dehydrated through a graded series of ethyl alcohol and embedded in liquid paraffin. Thin $(8 \mu \mathrm{m})$ sections were cut using a rotary automatic microtome (RM 2155-Leica) with disposable stainless steel blades; subsequently stained with toluidine blue, $\mathrm{pH} 7.0$, for $5 \mathrm{~min}$ [19], [20] for anatomical characterization and then washed with distilled water to remove dye 
residues. The staining process was adapted from [19] and [11]. Observations and photographs were taken using a Nikon TPL-210 stereo microscope and an Olympus UC30 U-Photo camera system.

\section{Results and Discussion}

\section{Effect of explant orientation and growth regulators on the embryogenic callus and total embryos formation}

In species such as alfalfa and soybean explant orientation is important for the induction of somatic embryos and the reason for this requirement is most probably due to the polar expression of one or several factors in plant lateral organs. In fact embryo formation is dependent on the species or genotype with which it is working [21].

In this context [22] indicates that the influence of cotyledon orientation in the embryogenic response could be due to the structural and physiological differences of the cells and tissues that exist on the abaxial and adaxial side of the cotyledon, which it ultimately determines the transport of auxins and therefore the embryogenic process. Additionally [23] - [25], suggests that the embryogenic potential of a tissue is related to its active role in nutrient transport. In this sense, it is important to highlight the key role of the use of cytokinins as BAP in 2.4D combination enhancing the formation of embryogenic calluses as indicated by [26] in cotyledons of Azadirachta indica. Likewise, other authors have stressed that the use of low auxin concentrations as growth regulators promotes the formation of regenerative callus of organogenic type, with root development and that high concentrations of these regulators promote the formation of non-regenerative callus [27] - [29].

Concerning the effect of plant growth regulators on the induction of embryos for Passiflora genus species da [30] observed that the addition of $4.5 \mu \mathrm{M}$ $\mathrm{BA}$ and $18.1 \mu \mathrm{M} 2,4 \mathrm{D}$ to the MS culture medium has a significant effect on embryo formation in P.incincnata. These results are similar to those of [31] for P. maliformis (4.5 $\mu \mathrm{M} \mathrm{BA}$ and 13.5 2,4D) and [15] for P. ligularis (4.5 $\mu \mathrm{M}$ BA and $27.2 \mu \mathrm{M})$. Several authors have pointed out that the explant
[32], the genotype of the plant [33], [34] and the cultivation conditions [35] are determinants in somatic embryogenesis.

With regard to $P$. mollissima var. mollisima the present study showed contrasting results whilst for the adaxial orientation the highest percentage of embryogenic callus was obtained at level $3(21.88 \%)$, for the abaxial orientation it was at level 1 (14.44\%), however, they were not statistically representative. On the other hand, the observed results of the effect of the growth regulators on the percentage of total embryo formation in the two planting orientations were similar and statistically significant for level 1 (4.5 $\mu \mathrm{M} \mathrm{BA}+4.5 \mu \mathrm{M} 2.4 \mathrm{D})$ (Table 1, Figure $1)$. In this level the explants (cotyledonary leaves) exhibited distinct morphological changes and turned to white green in color within a week of culture; and enlarged and swelled at their edges within the following two weeks of incubation showing the sign of dedifferentiation (Figure 1).
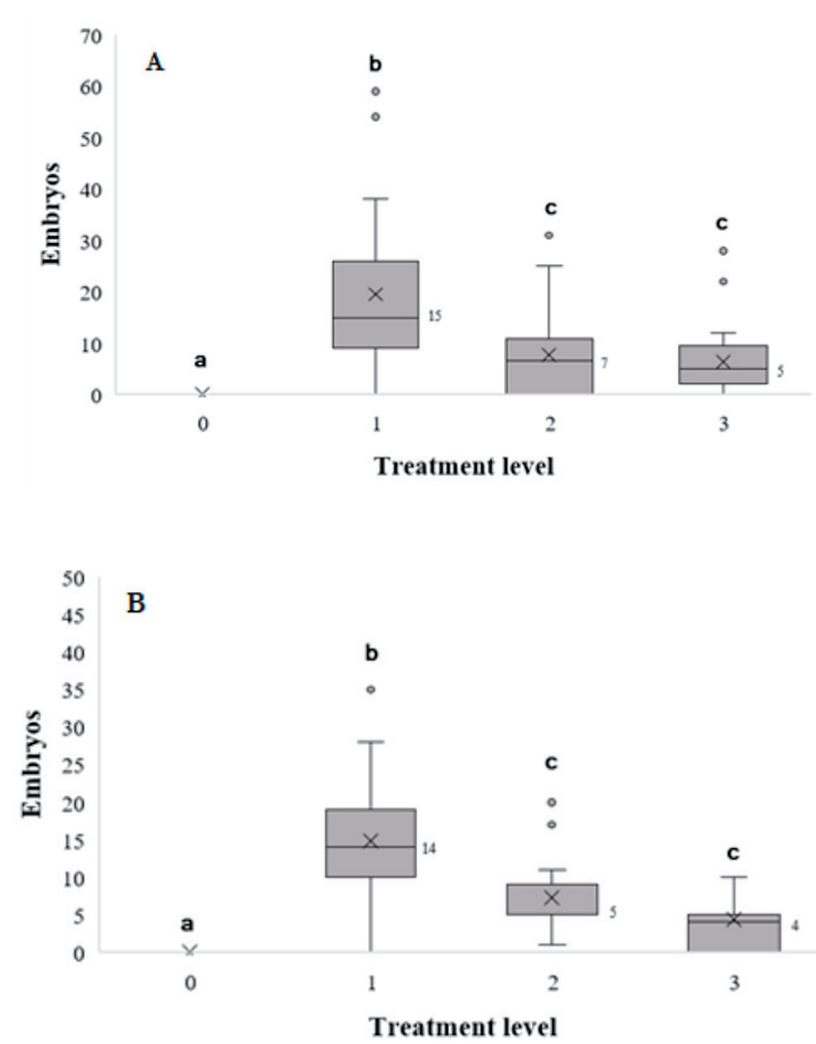

Figure 1. Effect of hormonal concentrations on the orientation of adaxial planting to the medium (A) and orientation of abaxial planting to the medium (B), on the number of embryos generated by the explants (bars with similar letters did not show statistically significant differences. $\alpha=0.05)(0=$ Without growth regulators; $1=4.5 \mu \mathrm{M} \mathrm{BA}+4.5 \mu \mathrm{M} 2.4 \mathrm{D} ; 2=4.5 \mu \mathrm{M} \mathrm{BA}+18.1 \mu \mathrm{M}$ $2.4 \mathrm{D} ; 3=4,5 \mu \mathrm{M} \mathrm{BA}+27.1 \mu \mathrm{M} 2.4 \mathrm{D}$. 
The explants formed white friable callus after 3 weeks of culture. De novo shoot bud induction was observed on the calli developed at the edges of explants. Additionally somatic embryogenesis was observed directly on the surface of the explant and the initial structure was visible after twelve days of establishment. Adaxial orientation embryos somatics were formed on the edges of the cotyledon leaves (Figure 2A, B) and for the abaxial orientation in the centre and on the edge of the explant, (Figure 2C, D). Regardless of the orientation of the explant on the culture medium somatic embryos were formed on the necrotic tissue and their size varied between 2.0 and $3.0 \mathrm{~mm}$ in length.

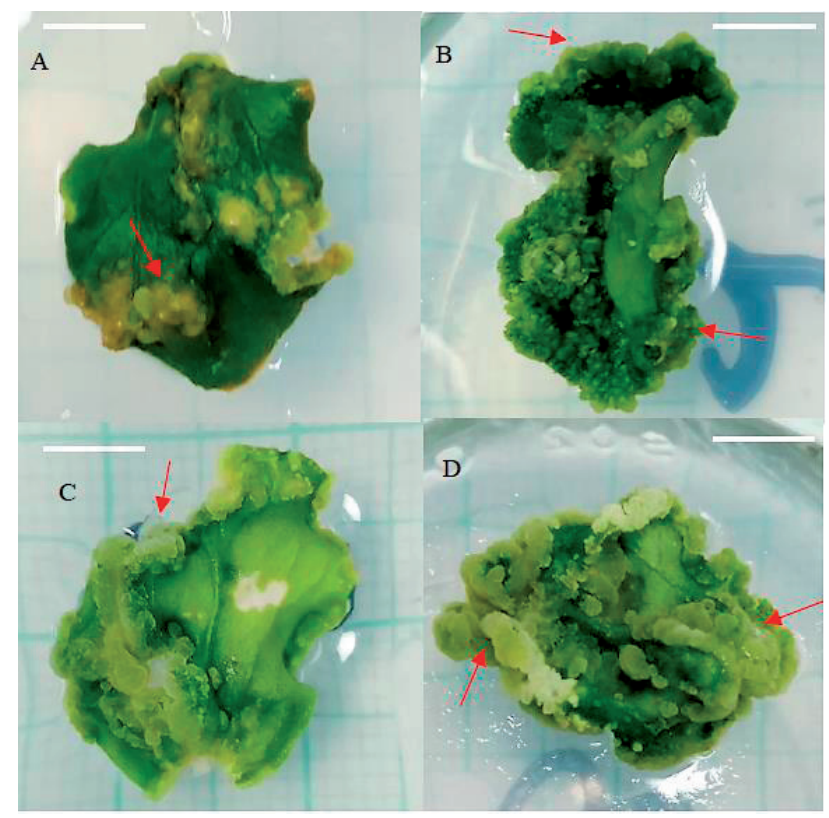

Figure 2. Embryogenic callus formation in cotyledone leaves adaxial upper face $(A, B)$ and abaxial lower face $(C, D)$.

\section{Determination of embryonic stages}

The morpho-anatomical analysis showed the development of an embryogenic type regenerative callus (EC), which had a compact appearance and greenish coloration on the surface of the edges of the cotyledonary leaves. From the EC, somatic embryos were differentiated according to the different stages globular (Figure 3A), heart (Figure 3B), torpedo (Figure 3C), cotyledon (Figure 3D, 3E) and mature (Figure 3F). Caulogenic regenerative callus were also observed with a greenish coloration; presenting primary structures similar to leaves (leaf primordia or buds). The formed callus showed small and isodiametric cells with a dense cytoplasm.

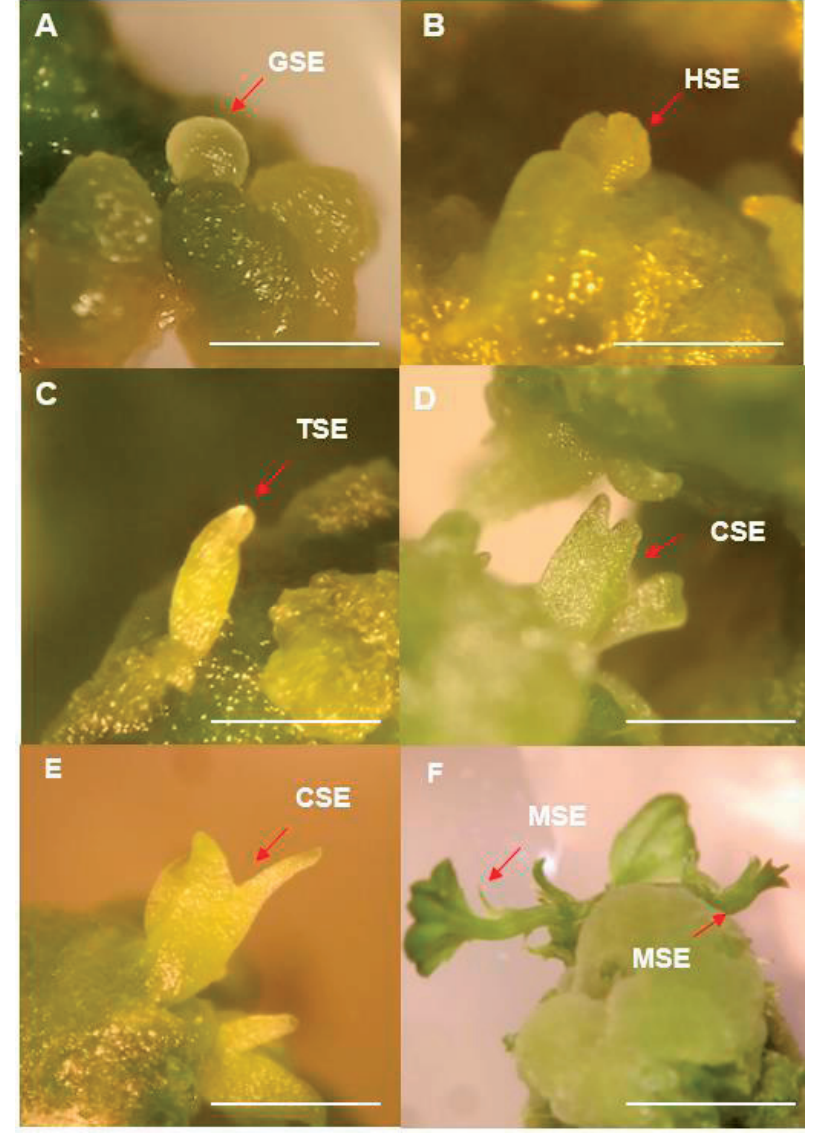

Figure 3. Determination of embryonic stages in leaf explants. A. Globular somatic embryo (GSE). B. Heart somatic embryo (HSE). C. Torpedo somatic embryo (TSE). Cotyledon somatic embryo. C SM Mature somatic embryo M $\mathrm{SE} \operatorname{Bar}=0.3 \mathrm{~cm}(\mathrm{~A}-\mathrm{E}) ; \mathrm{Bar}=0.5 \mathrm{~cm}(\mathrm{~F})$.

\section{Verification of somatic embryos by histological analysis}

Pro-embryogenic mass were found in which they were differentiated in meristematic nodules or packages (Figure 4AB). Through histological analysis of anatomical sections, anticlinal divisions of the epidermal cells and divisions of the mesophyll cells in various orientations in the cotyledonary region of the initial explant with $18 \mathrm{~d}$ of culture were observed, which is characteristic of the early formation of protuberances (Figure 4B).

A high proliferation rate for the induction of somatic embryos was obtained at the torpedo stage, even though further embryo development was observed, such as globular (Figure 4A, D, E), torpedo (Figure 4C, F) and cotyledon-staged embryos. Anatomical sections confirmed the similarity between the protuberances obtained in this work with those described for $P$. edulis [30], [36] and $P$. cincinnata [13]. These structures are considered as 
an intermediate stage between direct and indirect somatic embryogenesis since their formation precedes somatic embryo development [13], [30].

The present research represents the first study on the induction of somatic embryogenesis in P. mollissima using BA combined with and 2,4D. These results can be used as a starting point for establishing a complete regeneration cycle of somatic embryogenesis in $P$. mollissima, which has potential application for other passionfruit species.

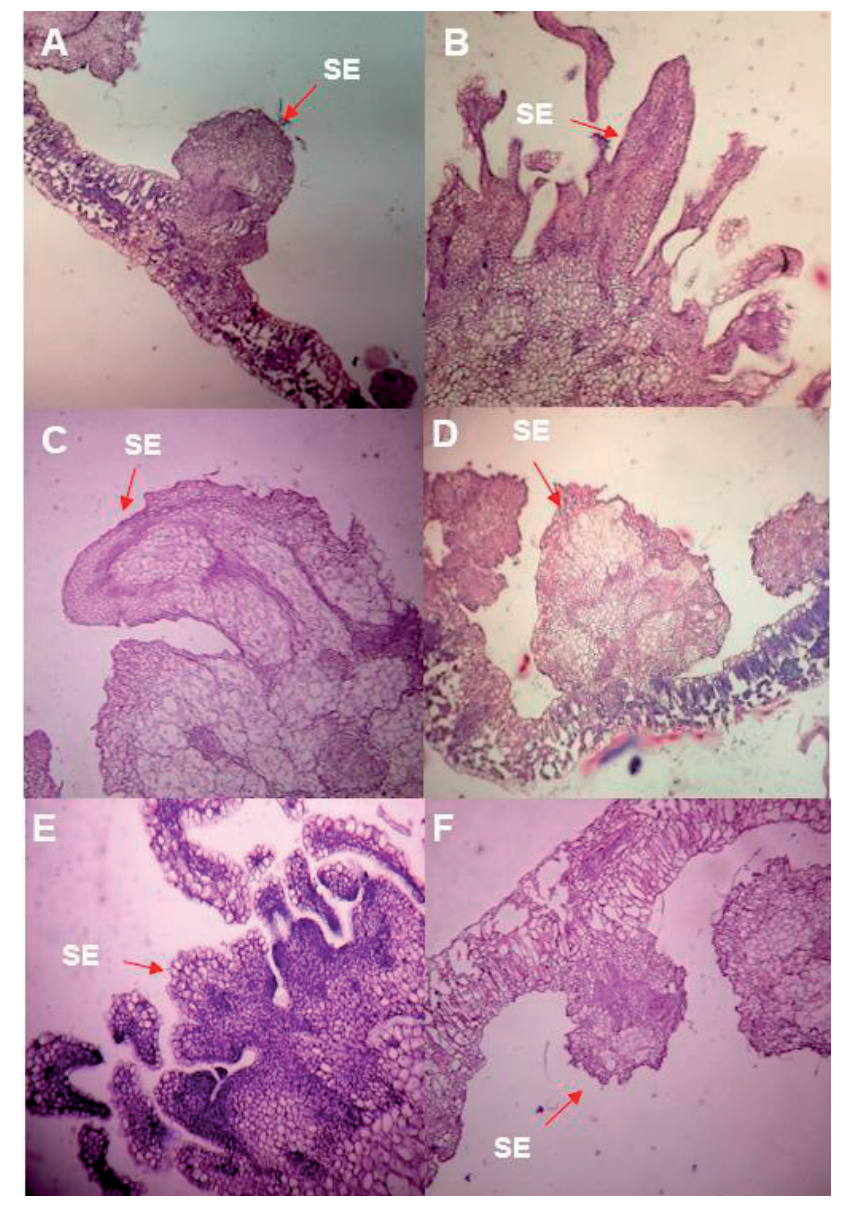

Figure 4. Histological analysis of the induction of somatic embryogenesis in foliar explants of $P$. mollissima Somatic embryos (SE). A. Somatic embryo in globular state (40x). B. Proembryogenic mass (40x). C. Somatic embryo in torpedo state (40x). D. Somatic embryo in globular state (40x). E. Somatic embryo in late globular state (40x). F. Somatic embryo in torpedo state (40x). G. Somatic embryo in globular state (40x).

\section{Conclusions}

The study allowed to determine the effect of planting orientation and hormonal concentrations on the development of embryonic tissue in foliar explants of $P$. mollissima var. mollisima. The concentrations of the $2.4 \mathrm{D}$ and BA growth regulators significantly influence the formation of somatic embryos, with the concentration of $4.5 \mu \mathrm{M} \mathrm{BA}+4.5 \mu \mathrm{M} 2.4 \mathrm{D}$ being the highest frequency presented for these variables.

\section{Acknowledgments}

Authors appreciate the support provided by the Universidad de Pamplona. Pamplona, North de Santander, Colombia.

\section{References}

[1] A. C. Aguirre-Morales, M. M. Bonilla-Morales and C. M. Caetano, "Passiflora franciscoi, a new species of Passiflora subgenus Astrophea (Passifloraceae) from Colombia", Phytotaxa, vol. 252, no. 1 pp. 56-62, 2016.

[2] R. C. Correa, R. M. Peralta, C. W. Haminiuk, G. M. Maciel, A. Bracht and I. C. Ferreira, "The past decade findings related with nutritional composition, bioactive molecules and biotechnological applications of Passiflora spp. (passion fruit)", Trends in Food Science and Technology, vol. 58, pp. 79-95, dic, 2016.

[3] M. Lobo and C. I. Medina, "Cultivo, Poscosecha y Comercialización de las Pasifloráceas en Colombia: Maracuyá, Granadilla, Gulupa y Curuba", Sociedad Colombiana de Ciencias Hortícolas, Bogotá, Colombia, 2009.

[4] A. C. Salazar and C. Ramírez, "Fruit maturity stage and provenance affect seed germination of Passiflora mollissima (banana passion fruit) and P. ligularis (sweet granadilla), two commercially valuable tropical fruit species", Seed Science and Technology, vol. 45, no. 2, pp. 383-397, 2017.

[5] M. Pires, A. de Almeida, A. de Figueiredo, F. Gomes and M. Souza. "Germination and seedling growth of ornamental species of Passiflora under artificial shade", Acta Scientiarum Agronomy, vol. 34, no. 1, pp. 67-75, 2012.

[6] M. Delanoy, P. Van Damme, X. Scheldeman and J. Beltran, "Germination of Passiflora mollissima (Kunth) L.H.Bailey, Passiflora tricuspis Mast. and Passiflora nov sp. seeds", Scientia Horticulturae, vol. 110, no. 2, pp. 198-203, 2006. 
[7] M. Ozarowski and B. Thiem, "Progress in micropropagation of Passiflora spp. to produce medicinal plants: A mini-review", Brazilian Journal of Pharmacognosy, vol. 23, no. 6, pp. 937-947, 2013.

[8] F. Nakayama, "Cultivo in vitro de tejidos de Passiflora caerulea", Revista de la Facultad de Agronomía de la Universidad Nacional de La Plata, vol. 42, no. 1, pp. 63-74, 1966.

[9] M. J. Moran-Robles, "In vitro vegetative multiplication of axillary buds of $P$. edulis var. flavicarpa Degener and P. mollissima Bairley", Fruits, vol. 33, pp. 701-715, 1978.

[10] G. Pacheco, M. Simão and M. Vianna, "In vitro conservation of Passiflora A review", Scientia Horticulturae, vol. 211, pp. 305-311, 2016.

[11] M. L. da Silva, D. Pinto, M. Guerra, E. Floh, C. H. Bruckner and W. C. Otoni, "A novel regeneration system for a wild passion fruit species (Passiflora cincinnata Mast.) based on somatic embryogenesis from mature zygotic embryos", Plant Cell, Tissue and Organ Culture, vol. 99, no. 1, pp. 47-54, 2009.

[12] D. Pinto, A. de Almeida, M. Rêgo, M. da Silva, E. de Oliveira and W. Otoni "Somatic embryogenesis from mature zygotic embryos of commercial passionfruit (Passiflora edulis Sims) genotypes", Plant Cell, Tissue and Organ Culture, vol. 107, no. 3, pp. 521-530, 2011.

[13] D. Rocha, L. Vieira, F. Tanaka, L. da Silva and W. Otoni, "Somatic embryogenesis of a wild passion fruit species Passiflora cincinnata Masters: histocytological and histochemical evidences", Protoplasma, vol. 249, no. 3, pp. 747-758, 2012.

[14] Y. Rosa and M. Dornelas, "In vitro plant regeneration and de novo differentiation of secretory trichomes in Passiflora foetida L. (Passifloraceae)", Plant Cell, Tissue and Organ Culture, vol. 108 no. 1, pp. 91-99, 2012.

[15] D. de Oliveira Prudente, R. Paiva, S. Carpentier, R. Swennen, F. Nery, S. L. Silva and B. Panis,
"Characterization of the formation of somatic embryos from mature zygotic embryos of Passiflora ligularis Juss", Plant Cell, Tissue and Organ Culture, vol. 131, no. 1, pp. 97-105, 2017.

[16] S. Khadke and A. Kuvalekar, "Direct somatic embryogenesis and plant regeneration from leaf and stem explants of Nothapodytes foetida: a critically endangered plant species", International Journal of Plant, Animal and Environmental Sciences, vol. 3, no. 1, pp. 257264, 2013.

[17] T. Murashige and F. Skoog, "A revised medium for rapid growth and bioassays with tobacco tissue culture", Physiologia Plantarum, vol. 15, pp. 473-479, 1962.

[18] C. A. Schneider, W. S. Rasband and K. Eliceiri, "NIH Image to ImageJ: 25 years of image analysis", Nature Methods, vol 9, no. 7, pp. 671, 2012.

[19] T. O'Brien, N. Feder and M. McCully, "Polychromatic staining of plant cell walls by toluidine blue O.”, Protoplasma, vol. 59, no. 2, pp. 368-373, 1964.

[20] T. O'Brien and M. McCully, The study of plant structure principles and selected methods, Melbourne: Termarcarphi Pty Ltd, 1981.

[21] P. Deo, A. Tyagi, M. Taylor, R. Harding and J. Becke, "Factors affecting somatic embryogenesis and transformation in modern plant breeding", The South Pacific Journal of Natural and Applied Sciences, vol. 28, no. 1, pp. 27-40, 2010.

[22] I. Bermúdez, T. Blanco, J. Pérez, L. García, N. Veitía and R. Collado, "Efecto de la orientación y la longitud del cotiledón inmaduro sobre la formación de embriones somáticos en dos genotipos cubanos de soya", Biotecnología Vegetal, vol. 10, no. 2, pp. 121-128, 2010.

[23] M. Griga, "Some factors affecting somatic embryogenesis efficiency in soybean (Glycine max [L.] Merrill)", Biologia Plantarum, vol. 35, no. 2, pp. 101-106, 1993. 
[24] J. Aparecida, M. L. Carneiro, I. Olívio and B. Appezzato "Anatomical study of somatic embryogenesis in Glycine max (L.) Merrill”, Brazilian Archives of Biology and Technology, vol. 45, no. 3, pp. 277-286, 2002.

[25] M. Ziv and J. Chen, "The anatomy and Morphology of Tissue Cultured Plants", In: George EF, Hall MA, Jan De Klerk, G (Eds) Plant Propagation by Tissue Culture, Springer. Dordrecht, 2008.

[26] G. Ranjan, "In vitro somatic embryogenesis in callus cultures of Azadirachta indica A. Juss. A multipurpose tree", Journal Forest Research, vol. 10, no. 1, pp. 263-267, 2005.

[27] S. Vila, H. Rey, A. Gonzalez and L. Mroginski "Somatic embryogenesis and plant regeneration in Cedrela fissilis", Biologia Plantarum, vol. 53, no. 2, pp. 382-386, 2009.

[28] P. Das, "In Vitro somatic embryogenesis in some oil yielding tropical tree species", American Journal of Plant Science, vol. 2, no. 1, pp. 217222, 2011.

[29] D. K. Das and A. Rahman, "Induction of somatic embryogenesis and long-term maintenance of embryogenic lines of litchi", Current Trends in Biotechnology and Pharmacy, vol. 7, no. 2, pp. 625-634, 2013.

[30] G. M. da Silva, A. Cruz, W. Otoni, T. Pereira, D. Rocha and M. da Silva, "Histochemical evaluation of induction of somatic embryogenesis in Passiflora edulis Sims (Passifloraceae)", In vitro Cellular \& Developmental Biology - Plant, vol. 51, no. 5, pp. 539-545, 2015.
[31] S. Bernal, L. Duarte, D. Rodríguez, D. L. Bohórquez, E. Araque and J. Pacheco, "Embriogénesis no zigótica en Passiflora maliformis Nonzygotic Embryogenesis in Passiflora maliformis", Revista Peruana de Biología, vol. 25, no. 3, pp. 281- 290, 2018.

[32] P. Sharma and M. V. Rajam, "Genotype, explant and position effects on organogenesis and somatic embryogenesis in eggplant (Solanum melongena L.)", Journal of Experimental Botany, vol. 46, no. 28, pp. 153-141, 1995.

[33] T. Radhakrishnan, T. G. K. Murthy, K. Chandran and A. Bandyopadhyay, "Somatic embryogenesis in Arachishypogea: revisited", Australian Journal of Botany, vol. 49, no. 6, pp. 753-759, 2001.

[34] C. K. Kim, J. D. Chung, S. O. Jee and J. Y. Oh, "Somatic embryogenesis from in vitro grown leaf explants of Rosa hybrida L.", Journal of Plant Biotechnology, vol. 5, no. 3 169-172, 2003.

[35] R. Zegzouti, M. F. Arnould and J. M. Favre. "Histological investigation of the multiplication steps in secondary somatic embryogenesis of Quercus robur L", Annals of Forest Science, vol. 58, no. 6, pp. 681-690, 2001.

[36] D. L. Paim Pinto, A. M. Almeida, M. M. Rêgo, M. L. Silva, E. J. Oliveira and W. C. Otoni. "Somatic embryogenesis from mature zygotic embryos of commercial passionfruit (Passiflora edulis Sims) genotypes", Plant Cell Tissue and Organ Culture, vol. 107, no. 3, pp. 521-530, 2011. 